\title{
The responses of the authoritarian national developmentalism to the structural economic crisis (1973-1985) ${ }^{1}$
}

\author{
As respostas politicas do nacional-desenvolvimentismo \\ autoritário à crise econômica estrutural (1973-1985)
}

CARLOS EDUARDO SANTOS PINHO*

\begin{abstract}
RESUMO: Esta pesquisa analisa a Crise Econômica Estrutural brasileira ao longo das décadas de 1970 e 1980 e as respostas políticas do Nacional-Desenvolvimentismo Autoritário (1964-1985). Em primeiro lugar, argumenta-se a respeito das crises internacionais do petróleo de 1973 e 1979, seguidas, neste último ano, do aumento (inesperado) das taxas de juros pelo Banco Central dos EUA e da restrição do crédito externo. Tais fatores contribuíram para a erosão do modelo de crescimento com endividamento externo, que fora exitoso durante o "milagre econômico" (1968-1973) em razão do elevado crescimento do PIB. O aumento das taxas de juros significou o fim do estado de liquidez no mercado financeiro de crédito internacional e o advento de uma política drasticamente recessiva no Brasil, agravando a crise fiscal do Estado e sucumbindo o modelo de industrialização por substituição de importações (ISI), que deu suporte ao Nacional-Desenvolvimentismo (1930-1985). A crise possui uma dimensão exógena e outra endógena, em virtude, respectivamente, da conjuntura externa adversa acima mencionada e do esgotamento da estratégia de crescimento com endividamento externo bem como da adoção, por parte da tecnoburocracia estatal, da ortodoxia convencional na gestão da política macroeconômica. Tais fatores abriram
\end{abstract}

\footnotetext{
${ }^{1}$ This article results from Post-doctoral research developed at the Instituto Nacional de Ciência e Tecnologia em Políticas Públicas, Estratégias e Desenvolvimento (INCT/PPED) (National Institute of Science and Technology on Public Policies, Strategies, and Development), advised by Professor Renato Raul Boschi, from April 2017 to February 2019, with a scholarship from the Brazilian Federal Agency for Support and Evaluation of Graduate Education (CAPES); and at the Graduate Program in Political Sociology at the State University of Northern Rio de Janeiro - Darcy Ribeiro (PPGSP-UENF), from November 2016 to February 2017, with a scholarship from the Research Support Foundation for the State of Rio de Janeiro (FAPERJ), advised by Professor Mauro Macedo Campos. I am grateful to the blind-reviewers of the Brazilian Journal of Political Economy, to the Editor-in-chief Luiz Carlos Bresser-Pereira, to Saulo Maia Said, and to Professors Pedro Paulo Zahluth Bastos and Ricardo Bielschowsky, scholars that contributed to perfect the arguments presented in this article. Any flaws or gaps are my exclusive responsibility.

* Professor and researcher at the Graduate Program in Social Sciences of the Universidade do Vale do Rio dos Sinos (PPGCS-UNISINOS), São Leopoldo/RS, Brazil. E-mail: cpinho19@unisinos.br. Orcid 0000-0003-0657-8906. Submitted: 21/January/2019; Approved: 17/July/2019.
} 
precedente para a degenerescência de um paradigma de desenvolvimento cujo processo decisório fora centralizado no Poder Executivo e marginalizador tanto da instância parlamentar/partidária quanto da sociedade civil e dos trabalhadores. A crise fiscal do Estado trouxe à tona a hegemonia do capitalismo financeiro rentista e não produtivo. Na segunda parte, o artigo analisa as externalidades negativas da crise econômica estrutural no plano social, tais como (1) o enfraquecimento do poder sindical enquanto veículo de canalização das demandas dos trabalhadores junto ao Estado e ao empresariado, (2) a disseminação do desemprego/subemprego nas regiões metropolitanas e do arrocho salarial, (3) o aumento da insalubridade nas relações laborais e, por fim, (4) o esgarçamento do tecido social, por conta da crença do Estado autoritário na (anti)estratégia recessiva para debelar a crise.

PALAVRAS-CHAVE: Nacional-desenvolvimentismo autoritário; crise econômica estrutural; dívida externa; recessão; desemprego; arrocho salarial; Brasil.

ABSTRACT: This research analyzes the Brazilian structural economic crisis throughout the 1970s and 1980s and the political responses of the Authoritarian National Developmentalism (1964-1985). Firstly, the study highlights the nature of the international oil crises of 1973 and 1979, showing an unexpected rise in interest rates by the US Central Bank and the tightening of external credit after 1979. Rising interest rates meant the end of liquidity in the international credit finance market and the beginning of a drastically recessive policy in Brazil. These factors contributed to the erosion of the growth model based on external debt, a model reflected in two main paradigms: the "economic miracle" (1968-1973) marked by high GDP growth rates; and the II National Development Plan (II PND) (1974-1979), focused on deepening the import substitution industrialization (ISI). The collapse of authoritarianism led to hyperinflation, external indebtedness, and the state's fiscal crisis, exposing the hegemony of rentier, nonproductive financial capitalism. The second part of the article investigates the negative externalities of the structural economic crisis at the social level, such as concentration, centralization, and closing of the decision-making process, hindering workers' participation; the intensification of union mobilizations for wage recomposition; the spread of unemployment/underemployment in metropolitan regions; the wage squeeze; the increase in unhealthy labor relations and, therefore, the thinning of the social fabric. KEYWORDS: Authoritarian national developmentalism; structural economic crisis; external debt; recession; unemployment; wage squeeze; Brazil.

JEL Classification: E44; F33; G15; N26; O23.

\section{INTRODUCTION}

The end of the period known as "economic miracle" (1968-1973), reflects the exhaustion of a vigorous cycle of economic expansion based on foreign debt. After a period of vast capitalist accumulation, the crisis of the Brazilian economy from 1974 undermined the pact of authoritarian domination in force, exposing contradictions within the ruling classes (Mantega and Moraes, 1979). In this scenario, the Authoritarian National Developmentalism (1964-1985) (PINHO, 2019) faced a prolonged structural economic crisis, despite the interstitial periods among high and low economic growths. This widespread crisis contributed to the erosion of 
the National Developmental State (1930-1985), based on the import substitution industrialization (ISI) model, diversification of the productive structure, expansion of the entrepreneurial state, and economic protectionism.

The economic literature produced at that time converged regarding the need to reestablish democracy to face the crisis. During the early 1980s, the major decisions on economic policy management were carried out through an extremely closed and concentrated decision-making process in the hands of the executive branch. This centralization reduced Brazil's opportunities to face the increasingly unfavorable conditions in the global economy.

The economists and social scientists studied in this article opposed to orthodox solutions to address these challenges and pointed to heterodox measures able to promote sustainable growth in the medium-term at the same time as reducing social inequalities. Moreover, they advocated for a state controlled by the civil society, institutionalizing a democratic regime and enabling participation of segments of society in defining public policy priorities. They advocated for a "new social pact," enabling greater transparency of government decision-making processes, as well as a more assertive action by the legislative branch in this direction. For them, democratization is an inalienable imperative to confront the internal social crisis, and economic policy must be recognized as the practical implementation of this task. Therefore, overcoming the crisis requires a new institutional arrangement antipode to authoritarianism (Furtado, 1977, 1982ab; Langoni, 1985; Mantega and Moraes, 1979; Monteiro, 1983; Serra, 1982; Tavares and Assis, 1985).

There was virtual exhaustion of the strategy based on the expansion of the state and the financing of development through external and internal indebtedness. In 1974, the source of imbalance was the trading account and oil imports. In 1982, the most significant impact occurred on the capital account through the sudden reversal of loan flows. The significant distinction among these two moments is whether there was a financial market. In 1974, the full functioning of the market allowed financing the imbalance. In 1982, this possibility ceased to exist, since the root of the crisis was in the market paralysis. It is worth noting that, on different occasions, there was a tendency to underestimate the violence of the events. Also, permanent phenomena were systematically misinterpreted as transitory, thus delaying the adoption of compensatory measures that could reduce the economic and social cost of the adjustment process (Langoni, 1985).

Latin America's per capita income reduced by approximately 14\% among 1982 and 1984. Brazil and Mexico, the two largest economies in the region at the time, experienced an unprecedented similar recessive process (especially in 1982 and 1983). Brazilian per capita income fell by $5.5 \%$ in 1983 , while Mexican GDP in the same year decreased by $5 \%$. The Brazilian crisis that emerged strongly in the period 1982 1984 was the end of an era. It is not, therefore, a cyclical crisis, or an event related to the context - both essentially transitory and likely to be overcome automatically by market forces. Also, it is not characterized as a simple liquidity crisis; indeed, external and internal financial imbalances represent only the "tip of the iceberg," the most visible part of deep structural imbalances (Langoni, 1985, p. 116). 
This article offers an analysis of the political responses of the Authoritarian National Developmentalism (1964-1985) to the severe structural economic crisis that deteriorated Brazil's social and political-institutional framework. The study reveals how the crisis affected the ability of the dictatorial state to plan national capitalist development. In this sense, government strategic planning is conceived from a macro-structural perspective largely covering the import substitution industrialization (ISI), the economic growth, the expansion of the entrepreneurial state, and the development of the productive capitalist regime. This strategic planning operates as a crucial instrument for governability in the context of authoritarian political institutions (Pinho, 2019). As a serious contingency imposed on authoritarian government planning, the structural crisis of the Brazilian political economy resulted from the inadequacy of the country's productive apparatus to the reality of the global economy. The origin of the crisis was the model of the economic growth that Brazil pursued during the 1970s and the impossibility of following this model in the long-term (Camargo, 1983).

The main research question addressed is 'What are the political responses of the Authoritarian National Developmentalism (1964-1985) to the Structural Economic Crisis (1973-1985) that broke down the National Developmentalism (19301985 ) as a development strategy based on the ISI, economic protectionism, expansion of the entrepreneurial state and diversification of the productive structure? The hypothesis is that the Structural Economic Crisis (1973-1985) affected the capacities ${ }^{2}$ of the Authoritarian National Developmentalism state, deteriorating the regime's political economy and aggravating the social issue, which was not a strategic priority of techno-bureaucracy, but rather the privileged treatment granted to economic elites attached to the state apparatus.

According to Peter Gourevitch's seminal work "Politics in Hard Times: Comparative Responses to International Economic Crises," which makes "political sociology of political economy," the international economy affects national policies by acting on domestic actors (Gourevitch, 1986, pp. 19-65). Thus, explaining the state's political choices requires mapping the profile of its production. This means analyzing the situation of social actors in the international economy; and to assess these actors' political preferences and their potential alliances or conflict with other emerging forces and coalitions (Gourevitch, 1986).

Based on this theoretical and conceptual framework, this study examines how the phenomenon of the structural economic crisis influenced the domestic politics of the dictatorial state, the reactions of the economic bureaucracy to exogenous contingencies, as well as the dynamics of political and economic coalitions. Above all, the research scrutinizes the social impacts of macroeconomic policies carried out by the elites of the Authoritarian National Developmental state, emphasizing the interaction among strategic actors such as the state, professionalized technobureaucracy, industrial businesspeople, unions, and the working class. It is impor-

\footnotetext{
${ }^{2}$ According to Celina Souza, the concept of 'state capacity' includes political, institutional, administrative, and technical variables. It is possible to define 'state capacity' as the state set of instruments and institutions used to establish goals, and elaborate and implement policies (Souza, 2016ab).
} 
tant to highlight the "new" transnational financial capitalism in the process of strong expansion, which imposes severe obstacles on the government's economic policy and determines the (tense) way of coordination among those national actors. The financial system rewards speculation and penalizes productive investment ( $\mathrm{Ta}$ vares and Belluzzo, 1982; Tavares, 1973, 1983).

The crisis takes on two specific dimensions. The first is exogenous due to the two oil shocks in 1973 and 1979; the unexpected rise in interest rates by the American FED in 1979; and the restriction of international credit to developing countries. The second dimension is of endogenous and cumulative nature, based on the 1980s debt crisis created by the use of external financing to support the development observed in previous decades. Moreover, the crisis led to mistakes in the technocratic management of macroeconomic policy, which followed an orthodox and recessive solution.

Methodologically, the research conducts a bibliographical survey, presenting an effort to establish a dialogue with the national and international literature of Economics, Political Economy of Development, and Political Science for the theoretical, conceptual, and critical appropriation of the long period analyzed. The article identifies, searches, systematizes, and empirical analysis data, generating graphs and tables that seek to connect theory and practice, as well as presenting a hypothesis.

The article is divided into four sections, including this introduction. The second section looks at the exogenous and endogenous conditions of the crisis, such as the 1973 and 1979 oil shocks, and the sharp rise in interest rates by the American FED in 1979. This section also explores the external debt crisis and the supremacy of financial capital, which led the Brazilian economy to bankruptcy mainly due to exponential inflation and the lack of strategic coordination on the part of policymakers working on the domestic macroeconomic policies. The third section highlights the negative externalities of the structural economic crisis on the labor market, trade unions, and the working class, who were already affected by a wage policy that concentrated income in the middle and upper classes since the establishment of the authoritarian regime in 1964. The fourth section offers the final considerations regarding the topics addressed in the research.

\section{"GLOBAL AND BRAZILIAN ECONOMY IN A MARCH TOWARD RECESSION" ${ }^{3}$ : OIL CRISES, SHOCK OF INTEREST, FISCAL CRISIS, AND EXTERNAL DEBT}

During the period of "economic miracle" (1968-1973), Brazil experienced growth with an unlimited supply of external credit at almost negative real interest

\footnotetext{
${ }^{3}$ The title of this section alludes to the classic work by Antônio Barros de Castro and Francisco Eduardo Pires de Souza "A Economia Brasileira em Marcha Forçada (1985) (The Brazilian Economy in a forced march).
} 
rates $^{4}$ (Bacha and Malan, 1986). The synchronized boom of the advanced economies in 1972-1973 led to an explosion in commodity prices that helped fuel the worst inflation the integrated economy of the capitalist world experienced. This situation lasted until 1974, when the world economy boomed, debt accumulated in a manageable manner, and euphoria developed. The breakdown of the Bretton Woods fixed parity system, and the acceleration of world inflation seemed to be events of secondary importance to Brazilian planners, who were, at that time, concerned solely with projecting past trends into dreams of the future (Bacha and Malan, 1988). When comparing the growth in the period of the "economic miracle," with the slowdown after 1974, it is possible to highlight three relevant distinctions: (1) the loss of dynamism in the industrial sector; (2) the damages caused by the first oil shock on the balance of payments; and (3) the recession and inflation acceleration in the world's economy. There is, however, an important commonality among the two periods: the expansion of international liquidity. Maintaining growth at historical rates during the period was feasible only due to using external debt, which delayed the adjustment of the economy to the new international context (Malan and Bonelli, 1983).

The first oil shock ${ }^{5}$ in late 1973 and early 1974 painfully showed that the euphoria had its costs and that a particular economic policy, stubbornly implemented to its limits, would outlast its usefulness (Bacha and Malan, 1988). The government's reaction to the rapid fall in the external accounts following the first oil shock was an attempt to stem the expansion of domestic demand to cope with the boom in imports and the accelerated inflation rate. This caused the real GDP growth rate to decline from $14 \%$ in 1973 to $9.8 \%$ in 1974 and $5.6 \%$ in 1975 , initiating a period of slowing growth (Carneiro, 1983, 1994; Resende, 1983; Werneck, 1983).

Faced with the modernizing goals of the national development plan (II PND), which envisioned Brazil as an 'island of prosperity' surrounded by the international crisis, the Finance Minister Mario Henrique Simonsen's strategic plan was cautious and less optimistic. Instead of subtly disregarding the difficulties to be imposed by the international crisis, Simonsen believed that the Brazilian economy should adapt to a period of lower growth rates. The minister put aside the idea of modernizing the industry, proposing to prioritize domestic investments related to including the Brazilian economy in the international market as an exporter of pri-

\footnotetext{
${ }^{4}$ The authors discuss the rise and fall of the Brazilian loans in the international credit market among 1968 and 1982. The three main periods are (1) the years of the "economic miracle" 1968-1973; (2) the attempt to "adjust" the economy 1974-1978; and (3) the critical period from 1979-1981, period in which political changes were not able to prevent the collapse of the exchange rate and the need to renegotiate the debt at the end of 1982 (Bacha and Malan, 1988).

${ }^{5}$ Fuel imports in Brazil went from $11.5 \%$ in 1973 to about $25 \%$ in 1975 . Oil prices went from the historical post-war level of US\$ 3 per barrel to close to US\$ 12 in 1974 . From 1974 to 1978 the prices remained among US\$ 12 and US\$15, growing again in 1979, reaching a peak of US\$ 37 in 1981 (Baer, 1978; Carneiro, 2002).
} 
mary commodities. The only structural reform in this context was a revision within the gasoline-based transport system to reduce the importance of the automobile industry and to encourage rail, river, and ship freight. As the II PND suggests investing in an import-substitution process financed by the external debt flow, Simonsen's strategy as an alternative to the II PND was much less interventionist and, therefore, more conservative, liberal, and monetary-oriented (Bastos, 1993). However, according to Antonio Barros de Castro and Francisco Souza, the 1974 crisis led the Brazilian economy to enter a long period of "forced march" and the II PND was presented as an alternative to austerity policies, since the plan promised to "jointly overcome the crisis and underdevelopment" (Castro and Souza, 1985, p. 33). The government sought to respond to external bottlenecks by restructuring the productive apparatus as well as refuting the idea that the market was capable of driving economic decisions (Castro and Souza, 1985).

History shows that "every recession of great magnitude is accompanied by a financial crisis of equal magnitude" (Bacha and Malan, 1988, p. 213), and both, recession and financial crisis, occurred in the early 1980s. The world economy went through a deep recession: the real GDP growth rate in OECD countries averaged less than 1\% in 1980-1982 (compared with 5.2\% from 1960 to 1973 and 2.7\% from 1974 to 1979 ). The real growth rate of world trade was slightly above $1 \%$ in 1980-1982 (compared to $8.6 \%$ from 1960 to 1973 and $4.5 \%$ from 1974 to 1979 ). The unemployment rate, as a percentage of the civilian workforce, averaged over $10 \%$ for OECD countries (compared to 3.1\% from 1960 to 1973 and $5.1 \%$ from 1974 to 1979) (Bacha and Malan, 1988; Resende, 1983).

The global oil crisis and Brazilian investment plans resulted in rapid growth in imports of sophisticated oil and capital goods, a growth that was not offset by expanding exports. The rise in the current account deficit led to massive foreign borrowing, resulting in an expansion in foreign debt from US\$ 10 billion in 1972 to over US $\$ 22$ billion by the end of 1975 . The drastic decrease in imports contributed to decreasing investments and, consequently, reducing the growth rate (BAER, 1978). Nevertheless, after the first oil shock, it was still possible to resort to the strategy of growth based on indebtedness due to the liquidity in the international financial market, which allowed real interest rates close to zero. The Brazilian advantage consisted of the expectation regarding increasing participation of the country's exports in the world market, which was likely to occur if there was no longlasting international recession (Bonelli, 1983).

In 1979, after the second oil shock, the situation was critical. It was aggravated by the effects of the economic policy of the new US administration after 1980, which brutally raised interest rates. Borrowing in US dollars became costly - and Brazil needed dollars to roll over foreign debt - and the international recession thwarted export expectations. The currency crises in Argentina and Mexico warned of the risks of a currency collapse in heavily indebted countries and inhibited currency lending (BAER, 1986; Bonelli, 1983; Lopes, 1983; Modiano, 1983; Resende, 1983).

The rise in the US interest rates at the end of 1979, however, was an essential 
measure for Americans to regain hegemony. The high interest in the US forced other advanced economies to a) obtain trade surpluses to finance capital account deficits, and b) implement monetary and fiscal restrictive policies to reduce domestic absorption. The outcome for these countries was a slower economic growth when compared to the so-called golden age, which ran from immediate post-World War II to the mid-1970s (Carneiro, 2002). The second oil price shock, the US recession, and the drastic rise in international interest rates ${ }^{6}$ triggered the most severe economic crisis in Brazil's independent history. In addition to encompassing political and economic aspects, the crisis was characterized by the fact that social actors (parts of the bourgeoisie, state techno-bureaucracy, and the working class) had no clear idea or project to overcome it. It became clear that there was not only a crisis on external accounts, but also a fiscal crisis of the state and, more broadly, a crisis of the developmental model. It was the Great Brazilian Crisis (Bresser-Pereira, 1982, 1990, 2003, 2014).

In the first half of 1979, Planning Minister Mario Henrique Simonsen, when faced with credit and fiscal disorder, tried to minimize the adverse effects of foreign debt and rehearsed the first steps of a recessive policy. However, unable to resist the backlash, he left the command of the economic area. His successor, Antônio Delfim Netto, sworn in on August 15, 1979, promised to maintain growth and took office with widespread and enthusiastic support from the business community. The new minister did not leave it out: in his speech, he firmly rejected the idea of recession and beckoned for a rapid reversal of inflation. However, this optimistic rhetoric was entirely incompatible, given the complexity of the context. Besides, the previous policy had deteriorated the economic policy instruments, mainly due to accelerating inflation, undermining the trust of the business community (Coutinho and Belluzzo, 1982ab).

Delfim Netto's option was to manage the crisis in a pragmatic and heterodox way, using strategies that raised less resistance, in order to gain room for the state to maneuver without falling into recession. To strengthen fiscal capacity, the government raised taxes and eliminated subsidies for exports with the currency overvaluation in 1979. Substantial price increases and fees charged by the public sector aimed to restore the self-financing levels of state-owned enterprises. The violent external rise in oil prices (100\% among mid-1979 and 1980), due to the fall of the Sha's regime in Iran, impacted intensely on the price system (Carneiro, 2002; Castro and Souza, 1985; Coutinho and Belluzzo, 1982ab; Macarini, 2008; Vianna, 1987).

This last orientation of the economic policy rapidly clashed with the external constraints. The country's liquidity position deteriorated in the second half of 1980 . Net international reserves fell from US\$ 7.9 billion in December 1979 to US\$ 3.2

\footnotetext{
${ }^{6}$ Nominal interest rate evolves from the pre-shock level of $5 \%$ to a range among $8 \%$ and $10 \%$ from 1974 and 1978, accelerating from that point to reach a peak of $19 \%$ in 1981 . Real interest rate remained practically constant and increased only after the second shock, i.e.,, in the 1980s (Carneiro, 2002).
} 
billion in September 1980 (Castro and Souza, 1985). Distrust over the economic policy throughout the 1980s quickly became widespread and engulfed external creditors. The international credit situation became increasingly tight from late 1979, when interest rates escalated, to a peak of $20 \%$ by April 1980 (Coutinho and Belluzzo, 1982ab).

Surrounded, on the one hand, by the sharp rise in oil prices and, on the other, by the rise in international interest rates, the government surrendered to the pressures of bankers who demanded higher spreads and commissions. Unable to cope with these pressures, watching the uncontrolled evasion of reserves, and victimized by the faults of its own prefixing policy, the government relented and, in November 1980, adopted the recessive policy. This policy consisted of the establishment of substantial quantitative restrictions on the expansion of bank credit and limitations on consumer credit, the release of interest rates, compression of government expenditures and investments of public companies, and a strong increase in Individual Income Tax. In addition, it sought to combine orthodox instruments - such as 'corrective' inflation and maxi-devaluation of the Brazilian currency at that time "Cruzeiro" - with heterodox instruments, such as price and interest controls, passive monetary policy, prefixing monetary and exchange correction well below expected inflation, and half-yearly wage increases. Its result was explosive for inflation, contributing, on the other hand, to a critical loss of reserves in the late 1980s. Indeed, the recession was produced to try to restore the credibility of economic policy drivers to the international financial community and avoid having to go to the IMF. The factors that favored the mismatch of the domestic economy are the instability of the international economy and the loss of autonomy of monetary and exchange rate policies. However, the recession did not bring the expected results due to the disarticulation of the international private credit market in September 1982. Brazil was then forced to approach the IMF and renegotiate its debts with banks. The effects of the recession were immediate and intense, with the sharp fall in industrial growth rates and the rapid formation of a massive contingent of unemployed people, especially in metropolitan areas ${ }^{7}$. The country entered a period when the cumulative fall in income was higher than that of the Great Depression of 1929. New restrictions on economic growth were inevitable, especially after the announcement of the Mexican moratorium in August 1982, making it clear that it would not be possible to persuade private bankers to continue doubling their bets on Brazil's long-term adjustment strategy. The Brazilian economy was practically stagnant in 1982, with real GDP growth of only $1.1 \%$. Therefore, when trying to explain the stagnation of Brazilian per capita income in the 1980s, one must point out among the reasons (besides the external crises of oil, interest, and external credit that characterized the first part of that decade) the adoption of conventional orthodoxy of those times. The crisis was not determined by the lack of government coordination, but by the political ineptitude engendered by the crisis

${ }^{7}$ The third section of this article presents further data on this matter. 
preventing government elites from adopting precise directions (Abreu and Fritsch, 1983; Arida, 1983ab; Bacha, 1983; Bacha and Malan, 1988; Carneiro, 1994; Carneiro and Modiano, 1990; Coutinho and Belluzzo, 1982ab; Cysne, 1984; Fishlow, 1986; Lago, 1983; Macarini, 2008; Malan, 1983; Mello and Belluzzo, 1982; Possas, 1983; Reichstul and Coutinho, 1983; Resende, 1983; Serra, 1982).

Table 1: Brazilian Economy: Synthesis of Macro-economic Indicators - 1974/1984 (annual means per period)

\begin{tabular}{|l|c|c|c|c|}
\hline \multicolumn{1}{|c|}{ Indicators } & $1974-1978$ & $1979-1980$ & $1981-1983$ & 1984 \\
\hline GDP growth (\% p.a.) & 6.7 & 8.0 & -2.2 & 5.4 \\
\hline $\begin{array}{l}\text { Inflation rate (IGP - general price } \\
\text { index, December/December, \% p.a.) }\end{array}$ & 37.8 & 93.0 & 129.7 & 223.9 \\
\hline GFCF (\% GDP in current prices) & 22.3 & 23.5 & 22.4 & 18.9 \\
\hline $\begin{array}{l}\text { Growth rate of exports of goods } \\
\text { (Current US\$, \% p.a.) }\end{array}$ & 15.3 & 26.1 & 2.8 & 23.3 \\
\hline $\begin{array}{l}\text { Growth rate of imports of goods } \\
\text { (Current US\$, \% p.a.) }\end{array}$ & 17.2 & 29.5 & -12.4 & -9.8 \\
\hline Trade balance (US\$ millions) & $-2,283$ & $-2,831$ & 2,818 & 13,090 \\
\hline $\begin{array}{l}\text { Current account balance (US\$ } \\
\text { millions) }\end{array}$ & $-6,548$ & $-11,724$ & $-11,584$ & 95 \\
\hline Net external debt/ exports of goods & 2.5 & 2.9 & 3.7 & 3.3 \\
\hline
\end{tabular}

Source: Hermann (2005, p. 106).

The context of the formation of the Brazilian foreign debt, which occurred over the years marked by the consumption of real and financial resources, can be divided into four distinct sub-periods. At the peak (1971-1973) of the period known as "economic miracle," the accumulation of reserves explains the increase in gross debt. In the following three periods (1974-1975, 1976-1978 and 1979-1980), the net indebtedness was the factor explaining, in varying proportions, the increase in gross debt. A key aspect of Brazil's external indebtedness process during the structural adjustment period concerns the growing nationalization of external debt. In 1974, the participation of the public sector in external debt was high, corresponding to approximately $50 \%$ of the total. From that moment onwards, participation continuously increased, reaching $69 \%$ in 1980 . The most critical period of the external debt nationalization was, therefore, connected to the II PND (1974-1979), which presented the leadership of state-owned companies and investments in infrastructure (Carneiro, 2002; Davidoff Cruz, 1983).

According to Luiz Carlos Bresser-Pereira, the domestic fiscal crisis and the external debt crisis are two essential phenomena to explain the macroeconomic imbalance in which Brazil was immersed. The public sector financial imbalance was created from the 1970s policy of growth based on indebtedness. Foreign debt 
was, in the 1980s, the backdrop of the Brazilian economic crisis and continued to be so in the 1990s. The decrease of the growth rate in the 1980s is explained, as direct causality, by the reduction in public investment rates, since the increase in commitments to pay interests resulted in negative public savings and, on the other hand, by the acceleration inflation, which disorganized investments or led them to inefficiency. The causes of reduced investment and increased inflation were the structural financial imbalance of the public sector (expressed in negative public savings), and the interconnected external debt. The importance of the interest rate on excessively high public (domestic and foreign) debt led to a decrease in the country's savings and investment capacity, an increase in the public deficit, and inflation. The fall in the investment rate was directly related to external debt. More precisely, with the increase of the real transfer of resources abroad (Bresser-Pereira, 2003).

The state fiscal crisis had two consequences. It reduced the state's savings (and consequently investment) capacity; and drove the public sector to print money to finance rising interest rates on foreign and domestic debt, accelerating inflation. The foreign debt crisis that began in the 1980s quickly turned into a fiscal crisis. More than that, Brazil faced, in the 1980s, a state crisis. The characteristics observed at that moment were the fiscal crisis, expressed as negative public savings and increased public indebtedness; the crisis in the form of state intervention, with the exhaustion of the import substitution model; and the crisis in the state's administration based on bureaucracy (Bresser-Pereira, 1990, 2003, 2014). The social (perverse) effects of the structural economic crisis that ended the National Developmental State (1930-1985) and the Authoritarian National Developmentalism (1964-1985) will be discussed in the next section.

\section{SOCIAL IMPACTS OF THE STRUCTURAL ECONOMIC CRISIS}

In addition to economic impacts, the structural economic crisis of the 1970s and 1980s - which culminated in the fiscal crisis, foreign indebtedness, and hyperinflation - had deleterious effects and contributed decisively to deteriorate the social fabric in Brazil. In this context, Celso Furtado pointed out that recession was observed particularly by the unemployment among workers perceiving a minimum wage and by the reduction of the real wage of middle-income groups. It is possible to argue, therefore, that there was a wage squeeze similar to that of the initial phase of authoritarianism (1964-1967), which prevented the recomposition of lower wages in real terms. Moreover, the prolonged recession took away the chance of compensating the loss of real family income. The fall in the population's purchasing power sought to deepen the recession, adapting the economy to the lowest level of imports, and enabling trade balances that should be increased to meet the demands of international creditors. Over the period 1970-1980, average labor productivity increased by $70 \%$, while average wages grew by only $50 \%$, whereas the minimum wage remained stagnant. The stagnation of the minimum wage accounted for the 
relatively slow growth of the average wage, as high wages grew more than average productivity, contributing to increasing social inequalities (Furtado, 1983).

Chart 1: Index of Real Minimum Wage (1965/1977)

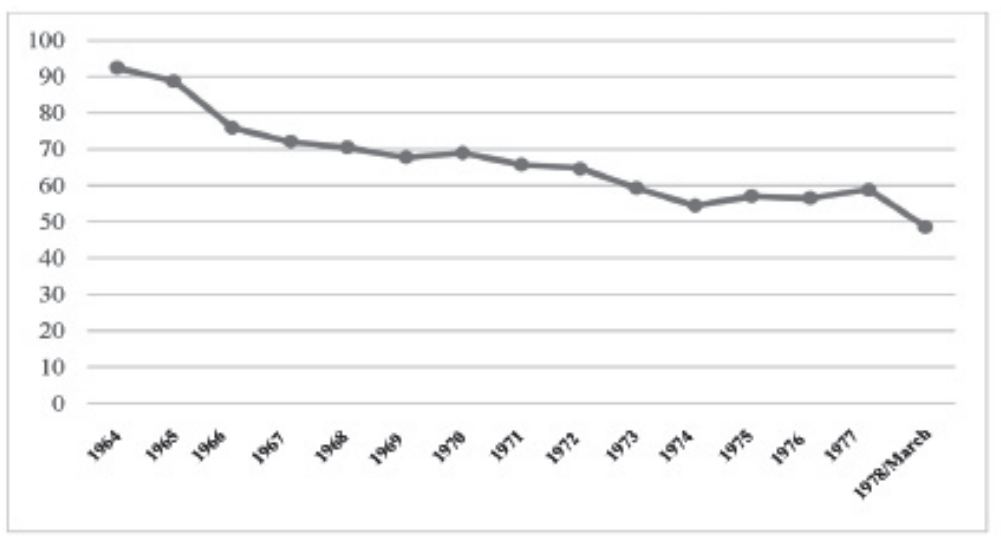

Source: Elaborated by the author, based on Mantega and Moraes (1979, p. 74).

From 1964 onwards, trade union negotiations abruptly stopped after intense repression, returning to the agenda in 1978, with strikes in São Paulo. The process of political liberalization of the military regime occurred amidst a profound economic crisis, severely affecting the population. Some of the consequences for the population was the rising cost of living, extreme wage squeeze, unemployment, the proletarianization of the urban middle class (Boschi, 1987), and loss of confidence in economic leaders. For the first time since the Law on Wages ${ }^{8}$ was enacted in November 1979, anchored in adjustments made every semester, the regime gave in to the demands of the trade unions and labor unrest, as inflation eroded the purchasing power of real wages. However, such a government response to wage demands was very ephemeral, short-term, and under strong state submission (Simões, 1986). During the period of the National Authoritarian Developmentalism (19641985) (Pinho, 2019), according to the Inter-Union Department of Studies and Research on Health and Workplace (DIESAT), Brazil was among the countries with the higher number of work accidents, counting over 1,9 million workers absent due to work accidents or illness. The levels of risk or unhealthy conditions leading to high accidental rates, derived from work processes that adopted a minimum of prevention measures. Thus, the worldwide capitalist crisis was present in Brazil with immense effects on the working class, stronger effects than that observed in other countries. One of the consequences in the relations among workers, state, and

\footnotetext{
${ }^{8}$ President Figueiredo's government chose to give in economically in order to obtain political advantages by softening the tensions among workers and political and union leaders that rise nationally (Sandroni, 1986).
} 
business, was the intensification of unemployment and the depreciation of working conditions. The government policy put the crisis' burden on the back of workers (Simões, 1986).

Workers with lower wages, no qualification, and shorter length of service were the most affected by turnover. The Fundo de Garantia por Tempo de Serviço (FGTS) (severance pay indemnity fund) reduced corporate burdens when establishing a compulsory monthly contribution of $8 \%$ of salaries, relieving them from other contributions that, together, exceeded the amount paid to the Fund. From the perspective of the labor relations, social security, and unions, the wage squeeze and the FGTS form a spoliation system, based on social security reforms and laws providing on unions' agency. Workers were obliterated, losing the right to strike, trade union autonomy, and power of collective bargaining. The lack of work stability and facility of replacing employees (even in case of illness or work-related accidents, which is observed by the numbers observed in the period of the "economic miracle") led to increasing rates of unemployment or underemployment, aggravated by the use and development of technology, in the urban centers and rural areas. The military regime adopted a technocratic policy managing Social Security along the lines of private companies, but at the same time, linked this scheme to the priority concept of National Security (Abranches, 1985; Belluzzo, 1975; Miglioli and Silva, 1983; Sá Earp and Prado, 2003; Simões, 1986; Singer, 1975ab; Tavares, 1975).

Against this adverse scenario, the level of industrial employment declined in the second semester of 1980. The fall accelerated from April 1981, when the issue of unemployment rate became a more relevant variable in political negotiation. At the same time, the unemployment benefits, created in 1965, were ineffective in dealing with the aggravated context. In January 1982, the unemployment was $12.6 \%$, higher than the rates of January 1981. Thousands of unemployed people accepted lower wages, or to work in different positions no matter their profession. Therefore, workers were disconnected from their unions in 1978. Drivers, welders, machine operators, and other specialized and semi-skilled metallurgical workers came to accept work such as bricklayer, bus and freight driver, and rural workers, for example, submitting to underemployment and odd jobs. Others remained unemployed, relying financially on their families. From March 1980 to March 1981, Brazil achieved the highest inflation rate in its history (exceeding $120 \%$ ), the highest net external debt to export value (2.64 in early 1980), and the highest unemployment rate in the country's six major cities (more than $8 \%$ in 1981 and 1982). The recessive policy adopted by Minister Delfim Netto since 1981 produced adverse effects on the lower classes. The recession and unemployment led to less social security payments from companies because of the payroll reduction or the increase in tax evasion. On the other hand, the poor working conditions, the records of work accidents, and the general decline in quality of life - intentionally reduced the consumption level of the working class in order to increase exports - heavily impacted workers' health (Sandroni, 1986; Simões, 1986).

The number of people earning less than the regional minimum wage grew by 
$72 \%$ among March and May 1981 in the six major metropolitan areas of the country (Table 2). The underemployment rate (the number of underemployed divided by the economically active population) doubled in Sao Paulo and Porto Alegre, regions where it was low and where unemployment was also lower. Underemployment rates in Belo Horizonte and Recife were around $20 \%$ and rose to $25 \%$ in Salvador. Adding the May 1981 unemployment rates to those of underemployment, $23 \%$ of the workforce in these six metropolitan areas was either unemployed or making less than the regional minimum wage. In other words, almost 1 in 4 economically active people were unemployed or underemployed and did not have access to adequate work (i.e.,, paying at least the minimum wage). In the metropolitan area of São Paulo, where the situation was relatively better than in the peripheral regions of the country, this proportion reached $20 \%$. In Salvador, the proportion was $35 \%$ and near $30 \%$ in Belo Horizonte and Recife. Together, there were almost 2.6 million workers in poor conditions regarding employment. The country's shortcomings in the areas of education, health, sanitation, housing ${ }^{9}$, and transportation were evident and worrying. These areas demanded unmatched public spending to overcome chronic social problems and improve employment (Souza, 1983).

Table 2: Underemployment rate in six metropolitan regions of Brazil* (Percentage of the workforce) - 1981

\begin{tabular}{|l|c|c|c|c|}
\hline \multirow{2}{*}{} & \multicolumn{2}{|c|}{ March/1981 } & \multicolumn{2}{c|}{ May/1981 } \\
\cline { 2 - 5 } & $\%$ & $\mathrm{~N}^{\circ}$ Underemployed & $\%$ & $\mathrm{~N}^{\circ}$ Underemployed \\
\hline São Paulo & 6.35 & 295,408 & 12.53 & 582,908 \\
\hline Rio de Janeiro & 8.11 & 279,487 & 13.19 & 454,553 \\
\hline Belo Horizonte & 12.39 & 122,983 & 19.01 & 188,693 \\
\hline Porto Alegre & 6.70 & 56,621 & 12.11 & 102,344 \\
\hline Recife & 15.31 & 108,915 & 19.33 & 110,432 \\
\hline Salvador & 13.39 & 76,497 & 25.0 & 178,419 \\
\hline Total & 8.36 & 939,911 & 14.41 & $1,617,346$ \\
\hline
\end{tabular}

Source: IBGE; Souza (1983, p. 150).

*People who work 40 hours (or more) per week, earning less than a minimum wage as established for the region they live. It is, therefore, a minimum estimation of underemployment.

\footnotetext{
${ }^{9}$ The Brazilian housing financial system (SFH) was a successful 'capitalist' solution to address the issue of housing and, in part, urban sanitation. At least it was successful until 1981. In 1983, it became ineffective at any level and turned into a general problem because wage policy was subordinated to the instructions of the IMF. The growth of the inflation rate resulted in widespread default (in 1984, more than $50 \%$ of the loans were not repaid). New mortgages were not feasible because of the fall in workers and middle-class real income. The crisis in SFH reproduced the global financial crisis on a national scale; in a way, its consequences were easily understood (Tavares and Assis, 1985).
} 
Economic policy as a whole had only one coherence: exclusion, keeping almost half of the Brazilian population segregated from outcomes of the development process. It was an internal exclusionary mechanism, connected to a strong and accelerated movement of financialization of the economy through the increasing internationalization of its modern sector, linked to international bank credit. At the base of the social pyramid, horizontal and spatial mobility resulted in the emergence of pockets of poverty. Millions of rural workers went to large cities looking for subsistence, working primarily in construction, living in peripheral areas, and marginality. In the industry, the age of over $70 \%$ of workers ranged from 18 to 24 years old. As job stability - a feature appreciated in Japan but overturned by the Brazilian business community and the multinational corporation installed in the country - was finished, the rotation of the workforce expelled the working population as if people were burnt oil. The informal labor market loomed, and female participation increased. Each family sought to double the number of members in the labor force to pay for the same amount of food and conditions to survive (Tavares and Assis, 1985). According to data from the InterUnion Department of Statistics and Socioeconomic Studies (DIEESE), the working time needed to buy a "cesta básica," (i.e.,, specific basic food established by Brazilian law, supposed to feed a family for one month) with the minimum wage had risen from 138 hours and 3 minutes in 1978 to 163 hours and 44 minutes in 1981. In 1983, for the first time since the beginning of the studies carried out by DIEESE, the price of the "cesta básica" exceeded the monthly minimum wage (Chart 2) (Keck, 1988, p. 406). The cost of food, rent, and transportation increased, whereas the relative prices for home appliances and cars decreased. Thus, the market as a whole expanded, but the patterns of production and consumption were distorted when considering the concrete needs of Brazilian society (Tavares and Assis, 1985).

Chart 2 illustrates more or less what the discussion above regarding the working hours, less intuitively, tried to show. The chart is formed with two graphs and shows the evolution (in 'Cruzeiros' Cr\$ - Brazilian currency at that time) of the minimum wage value and the cost of the cesta básica (top graph), as well as the proportion of the first, used to purchase the latter (bottom graph). The advantage of seeing both graphs in the same chart is the facility to understand when the salary is "buying less," (bottom graph) and why it is "buying less" (top graph). For example, the bottom graph shows that among 1972 and 1973, the proportion of the minimum wage spent on the cesta básica went up from 0.49 to 0.69 . The top graph explains that the change in the proportion occurred because the cost of the cesta básica increased, while the minimum wage did not increase at the same pace. 


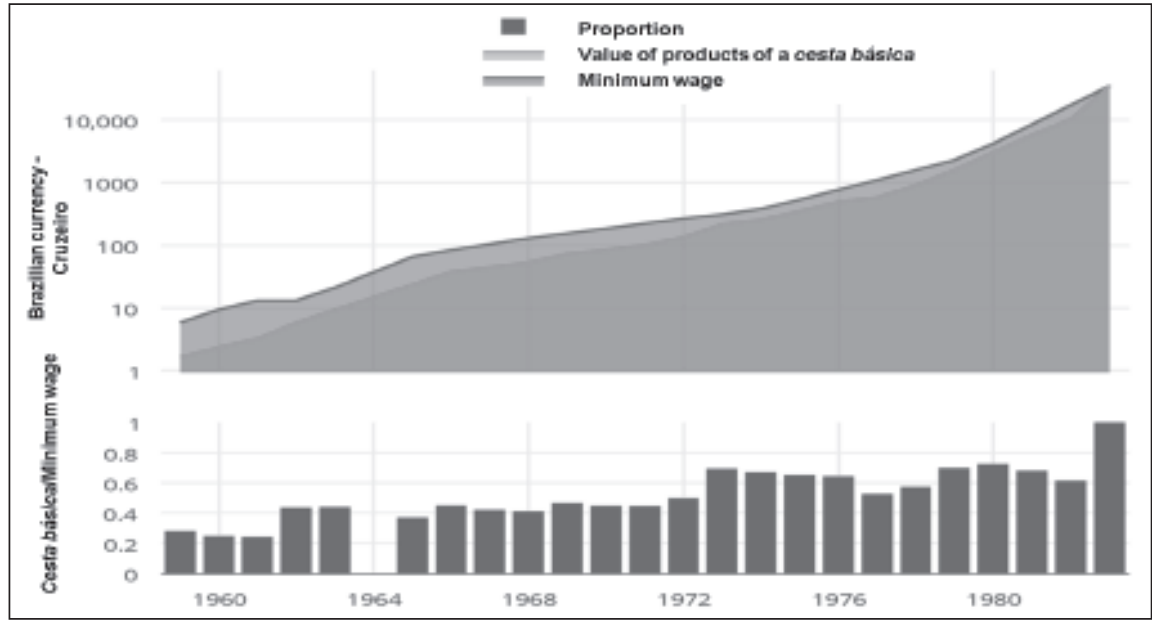

Source: Elaborated by the author using the software Plotly, based on Keck (1988, p. 406).

* "Cesta Básica," as mentioned before in this article, refers to specific basic food established by Brazilian law, supposed to feed a family for one month.

\section{FINAL CONSIDERATIONS}

This article examined the political responses of the Authoritarian National Developmentalism (1964-1985) in Brazil to the 1970s and 1980s structural economic crisis. In Latin America and particularly in Brazil, the crisis led to the dissolution of the National Developmental State (1930-1985), which was based on the diversification of the productive structure, expansion of the entrepreneurial state, economic protectionism, and on the model of import substitution industrialization (ISI).

Firstly, exogenous factors such as the 1973 and 1979 oil crises, the sharp rise in interest rates in the US in 1979, the credit and liquidity decrease in the international financial market, all converged to intensify the fiscal crisis, indebtedness, and the hyperinflation in Brazil. The crisis in the US financial system, stemming from the unexpected rise in interest rates, largely explains why the developed countries' financial system (bankers) and the IMF were relentless with Latin America. Considering a rational capitalist perspective, needed to save their banks.

Secondly, endogenous factors also contribute to aggravate the crisis. Among these factors, stands out the political incapacity and the poor decision-making of technocrats responsible for the macro-economic management, who wrongly adopted recessive policies. If the structural economic crisis, in the case of Brazil, converged to the collapse of the National Developmentalism (1930-1985) as an institutional legacy of the history of the capitalist development; in Europe, the same crisis culminated in the suppression of the social-democratic welfare state estab- 
lished after World War II, based on strong social policies and on the pact among capital and labor.

As for the behavior of the domestic actors, the national financial capitalism was subordinated to the international financial capital in a coalition of liberal and rentier nature to the detriment of the national productive sector and the working class, which was subject to wage squeeze and demeaning working conditions. Wage squeeze also hit the middle class, which underwent a process of impoverishment. Based on an extremely centralized, closed, and insulated decision-making process, technocrats responsible for the macroeconomic management led the dictatorial state to adopt a recessive policy, in an attempt to restore credibility among the international financial community. The consequence was the loss of national autonomy and sovereignty over economic policy-making, hampering the ability to create an alternative to the recession imposed by the IMF.

In addition to the loss of autonomy, there was the dollarization of the private financial system and the public enterprise system, which led to internal and external financial insolvency. This process tied the fate of the Brazilian economy as a whole and the functioning and expansion of the public and private financial sectors, to the misfortune of the uncontrolled evolution of the international credit system. When this system collapsed in 1982, Brazil was on the brink of bankruptcy and turned to the IMF to renegotiate its debt. The team of economists in the government, demoralized and despised even by the rich and the very rich who benefited the most from their decisions, left a huge bill to the New Republic (1985): a country's external debt; the public sector's internal debt; and the social debt left by the beneficiaries of two decades of authoritarianism (Tavares and Assis, 1985).

As for social depletion, the national business community relied on the authoritarian state to reduce workers' rights by removing job stability - revealing a centralized and exclusionary development model. In the face of growing social demands, the Law on Wages enacted in 1979 had no effect, as inflation progressively consumed the wages and income of the working classes. In short, the political responses of the Authoritarian National Developmentalism (1964-1985) (Pinho, 2019) to the structural economic crisis of the Brazilian state formed a mix of loss of sovereignty in the management of macroeconomic policy, unemployment, underemployment, increased informality, rural flight (due to the increasing poverty in rural areas), formation of favelas, urban poverty, wage squeeze, and, therefore, deterioration of the social fabric.

It is possible to say that the 1979 crisis threw Latin America and Brazil into a severe fiscal emergency. As a result, the 1980s was marked by labor and union pressure for wage improvements, a demand that had been deliberately excluded during the period known as the "economic miracle" (1968-1973) and ignored in the development model adopted by the Authoritarian National Developmentalism. In addition, the agendas of development and income redistribution were weakened and replaced with the monetary stabilization agenda and the guidelines of the fiscal austerity in the public accounts, especially in the 1990s. The context resulting from the sequence of facts observed during the 1970s and 1980s was ideal for imple- 
menting and consolidating the neoliberal orthodoxy of the Washington Consensus. This new approach was critical for the developmental state and would be hegemonic in Brazil from the 1990s to 2005, at the end of the first term of President Lula da Silva (2003-2006).

\section{REFERENCES}

ABRANCHES, Sérgio Henrique. (1985), Os Despossuidos: crescimento e pobreza no país do milagre. Rio de Janeiro: Jorge Zahar Ed.

ABREU, Marcelo de Paiva e FRITSCH, Winston. (1983), “As Lições da História: 1929 e 1979?” In: ARIDA, Pérsio (Org.), Dívida Externa, Recessão e Ajuste Estrutural: o Brasil diante da crise. Rio de Janeiro: Paz e Terra.

ARIDA, Pérsio. (1983a), "Introdução” In: ARIDA, Pérsio (Org.), Dívida Externa, Recessão e Ajuste Estrutural: o Brasil diante da crise. Rio de Janeiro: Paz e Terra.

ARIDA, Pérsio. (1983b), “Austeridade, Autotelia e Autonomia” In: ARIDA, Pérsio (Org.), Divida Externa, Recessão e Ajuste Estrutural: o Brasil diante da crise. Rio de Janeiro: Paz e Terra.

BACHA, Edmar L. (1983), "Por uma Política Econômica Positiva” In: ARIDA, Pérsio (Org.), Dívida Externa, Recessão e Ajuste Estrutural: o Brasil diante da crise. Rio de Janeiro: Paz e Terra.

BACHA, Edmar. L. e MALAN, Pedro. S. (1988), “A dívida externa brasileira: do milagre ao Fundo". In: Alfred Stepan (Org.). Democratizando o Brasil. Rio de Janeiro: Paz e Terra.

BAER, Mônica (1986), A internacionalização financeira no Brasil. Petrópolis: Vozes.

BAER, Werner. (1978), “O Crescimento brasileiro e a Experiência do Desenvolvimento: 1964-1975”. In: ROETT, Riordan (Org.), O Brasil na Década de 1970. Rio de Janeiro: Zahar Editores.

BASTOS, Pedro Paulo Zahluth. (1993), “A Privatização da Política Econômica: Vetos Neo-Liberais, Crise do Estado Desenvolvimentista e Conflitos Político/Empresariais no Brasil - 1974/1976”. Relatório final de Monografia. Instituto de Economia: UNICAMP, Novembro.

BELLUZZO, Luiz Gonzaga M. (1975), "Distribuição de renda: uma visão da controvérsia”. In: TOLIPAN, Ricardo e TINELLI, Arthur Carlos. (Orgs.). A Controvérsia sobre Distribuição de Renda e Desenvolvimento. Rio de Janeiro: Zahar Editores.

BONELLI, Regis. (1983), “Investimento e Emprego Face a Desequilíbrios Externos e Internos” In: ARIDA, Pérsio (Org.), Dívida Externa, Recessão e Ajuste Estrutural: o Brasil diante da crise. Rio de Janeiro: Paz e Terra.

BOSCHI, Renato. (1987), A Arte da Associação: Política de base e democracia no Brasil. São Paulo: Vértice, Editora Revista dos Tribunais; Rio de Janeiro: IUPERJ.

BRESSER-PEREIRA, Luiz Carlos. (1982), A Sociedade Estatal e a Tecnoburocracia. São Paulo: Editora Brasiliense.

BRESSER-PEREIRA, Luiz Carlos. (1990), “Da crise fiscal à redução da dívida”. In: VELLOSO, João Paulo dos Reis (Org.), Dívida Externa e Desenvolvimento. Rio de Janeiro: José Olympio.

BRESSER-PEREIRA, Luiz Carlos. (2003), Desenvolvimento e Crise no Brasil: história, economia e política de Getulio Vargas a Lula. São Paulo: Editora 34.

BRESSER-PEREIRA, Luiz. C. (2014), A Construção Política do Brasil: Sociedade, Economia e Estado desde a Independência. São Paulo: Editora 34.

CAMARGO, José Márcio. (1983), “Do Milagre à Crise” In: ARIDA, Pérsio (Org.), Dívida Externa, Recessão e Ajuste Estrutural: o Brasil diante da crise. Rio de Janeiro: Paz e Terra.

CARNEIRO, Dionísio Dias. (1983), “O Terceiro Choque: é possível evitar-se a depressão?” In: ARIDA, Pérsio (Org.), Dívida Externa, Recessão e Ajuste Estrutural: o Brasil diante da crise. Rio de Janeiro: Paz e Terra.

CARNEIRO, Dionísio Dias. (1994), “1974-1994: os desafios da estabilização postergada”. In: LAMOUNIER, Bolívar, CARNEIRO, Dionísio D. e ABREU, Marcelo de P. (Orgs.). 50 anos de Brasil: 50 anos de Fundação Getulio Vargas. Rio de Janeiro: Editora FGV. 
CARNEIRO, Dionísio Dias. e MODIANO, Eduardo. (1990), “Ajuste Externo e Desequilíbrio Interno: 1980-1984”. In: Marcelo de Paiva Abreu (Org.). A Ordem do Progresso: Cem Anos de Política Econômica, 1889-1989. Rio de Janeiro: Elsevier.

CARNEIRO, Ricardo. (2002), Desenvolvimento em crise: a economia brasileira no último quarto do século XX. São Paulo: Ed. Unesp/Ed. Unicamp.

CASTRO, Antonio Barros de e SOUZA, Francisco E. P. de (1985), A Economia Brasileira em Marcha Forçada. Rio de Janeiro: Paz e Terra.

COUTINHO, Luciano G. e BELLUZZO, Luiz G. de M. (1982a), "Política Econômica, Inflexões e Crise” In: BELLUZZO, Luiz Gonzaga M. e COUTINHO, Renata (Orgs.), Desenvolvimento Capitalista no Brasil: Ensaios sobre a Crise. Brasiliense: São Paulo, vol.1.

COUTINHO, Luciano G. e BELLUZZO, Luiz G. de M. (1982b), “Estado, Sistema Financeiro e Forma de Manifestação da Crise: 1929-1974”, In: BELLUZZO, Luiz Gonzaga M. e COUTINHO, Renata (Orgs.), Desenvolvimento Capitalista no Brasil: Ensaios sobre a Crise. Brasiliense: São Paulo, vol.1.

CYSNE, Rubens. P (1994), “A economia brasileira no período militar”. In: Gláucio Ary Dillon Soares, Maria Celina D’Araújo (Orgs.). 21 Anos de Regime Militar: balanços e perspectivas. Rio de Janeiro: FGV.

DAVIDOFF CRUZ, Paulo R. (1982), Endividamento Externo e Transferência de Recursos Reais ao Exterior: os Setores Público e Privado na Crise dos anos Oitenta. UNICAMP, Campinas (mimeo).

FISHLOW, Albert (1986), “A Economia política do ajustamento brasileiro aos choques do petróleo: uma nota sobre o período 1974/1984". Pesquisa e Planejamento Econômico, vol. 16, n. 3, dezembro, p. 507-550.

FURTADO, Celso. (1977), Prefácio à Nova Economia Política. Rio de Janeiro: Paz e Terra.

FURTADO, Celso. (1982a), O Brasil pós-milagre. Rio de Janeiro: Paz e Terra.

FURTADO, Celso. (1982b), A Nova Dependência: dívida externa e monetarismo. Rio de Janeiro: Paz e Terra.

FURTADO, Celso. (1983), Não à Recessão e ao Desemprego. Rio de Janeiro: Paz e Terra.

GOUREVITCH, Peter (1986), Politics in Hard Times: Comparatives Responses to International Economic Crises. Ithaca: Cornell University Press.

HERMANN, Jennifer. (2005), “Auge e declínio do Modelo de Crescimento com Endividamento: O II PND e a Crise da Dívida Externa”, In: Economia Brasileira Contemporânea. Fabio Giambiagi, André Villela, Lavínia Barros de Castro e Jennifer Hermann (Orgs.). Rio de Janeiro: Editora Campus/Elsevier.

KECK, Margaret E. (1988), “O ‘novo sindicalismo’ na transição brasileira”. In: Alfred Stepan (Org.). Democratizando o Brasil. Rio de Janeiro: Paz e Terra.

LAGO, Luiz Aranha Corrêa do. (1983), "A Programação do Setor Externo em 1983: uma breve análise crítica” In: ARIDA, Pérsio (Org.), Dívida Externa, Recessão e Ajuste Estrutural: o Brasil diante da crise. Rio de Janeiro: Paz e Terra.

LANGONI, Carlos. G. (1985), A Crise do Desenvolvimento: uma estratégia para o futuro. Rio de Janeiro: José Olympio.

LOPES, Francisco L. (1983), “A Crise do Endividamento Externo: alguns números e suas consequências” In: ARIDA, Pérsio (Org.), Dívida Externa, Recessão e Ajuste Estrutural: o Brasil diante da crise. Rio de Janeiro: Paz e Terra.

MACARINI, José P. (2008), “Crise e política econômica: o Governo Figueiredo (1979-1984)”, Texto para discussão. IE/UNICAMP, Campinas, n. 144, junho.

MALAN, Pedro Sampaio. (1983), "Recessão e Renegociação” In: ARIDA, Pérsio (Org.), Dívida Externa, Recessão e Ajuste Estrutural: o Brasil diante da crise. Rio de Janeiro: Paz e Terra.

MALAN, Pedro; e BONELLI, Régis. (1983), "Crescimento econômico, industrialização e balanço de pagamentos: o Brasil dos anos 70 aos anos 80". Texto para Discussão, n. 60, nov. Rio de Janeiro: IPEA/INPES.

MANTEGA, Guido e MORAES, Maria. (1979), Acumulação Monopolista e Crises no Brasil. Rio de Janeiro: Paz e Terra. 
MELLO, João M. C. de e BELLUZZO, Luiz G. de M. (1982), "Reflexões sobre a Crise Atual” In: BELlUZZO, Luiz Gonzaga M. e COUTINHO, Renata (Orgs.), Desenvolvimento Capitalista no Brasil: Ensaios sobre a Crise. Brasiliense: São Paulo, vol.1.

MIGLIOLI, Jorge e SILVA, Sérgio. (1983), "Redistribuição: Um Problema de Salários e Lucros” In: BELlUZZO, Luiz Gonzaga M. e COUTINHO, Renata (Orgs.), Desenvolvimento Capitalista no Brasil: Ensaios sobre a Crise. São Paulo: Brasiliense, vol.2.

MODIANO, Eduardo M. (1983), “Choques Externos e Preços Internos: dificuldades da política de ajuste” In: ARIDA, Pérsio (Org.), Divida Externa, Recessão e Ajuste Estrutural: o Brasil diante da crise. Rio de Janeiro: Paz e Terra.

MONTEIRO, Jorge Vianna. (1983), “Organização e Disfunções da Política Econômica” In: ARIDA, Pérsio (Org.), Dívida Externa, Recessão e Ajuste Estrutural: o Brasil diante da crise. Rio de Janeiro: Paz e Terra.

PINHO, Carlos E. S. (2019), Planejamento Estratégico Governamental no Brasil: Autoritarismo e Democracia (1930-2016). Curitiba: Appris.

POSSAS, Mario Luiz. (1983), "Empresas Multinacionais e Industrialização no Brasil: notas introdutórias” In: BELLUZZO, Luiz Gonzaga M. e COUTINHO, Renata (Orgs.), Desenvolvimento Capitalista no Brasil: Ensaios sobre a Crise. São Paulo: Brasiliense, vol.2.

REICHSTUL, Henri Philippe e COUTINHO, Luciano G. (1983), "Investimento Estatal 1974-1980: Ciclo e Crise” In: BELLUZZO, Luiz Gonzaga M. e COUTINHO, Renata (Orgs.), Desenvolvimento Capitalista no Brasil: Ensaios sobre a Crise. São Paulo: Brasiliense, vol.2.

RESENDE, André Lara. (1983), “A Ruptura no Mercado Internacional de Crédito” In: ARIDA, Pérsio (Org.), Dívida Externa, Recessão e Ajuste Estrutural: o Brasil diante da crise. Rio de Janeiro: Paz e Terra.

SÁ EARP, Fabio e PRADO, Luiz Carlos Delorme. (2003), “O Milagre Brasileiro: crescimento acelerado, integração internacional e concentração de renda (1967-1973)" In: Ferreira, J. e Delgado, L. (Orgs). O Tempo da Ditadura: regime militar e movimentos sociais em fins do século XX. Coleção O Brasil Republicano. Vol. 4. Rio de Janeiro: Civilização Brasileira.

SANDRONI, Paulo. (1986), “Brasil: A Recuperação Taciturna” In: Paulo Sandroni (Org.), Constituinte, Economia e Política da Nova República. São Paulo: Cortez.

SIMÕES, Carlos. (1986), A Lei do Arrocho: Trabalho, Previdência e Sindicatos no Regime Militar 1964/1984. Petrópolis: Vozes.

SERRA, José. (1982), "Ciclos e mudanças estruturais na economia brasileira do pós-guerra". In: BELlUZZO, L. G. M., COUTINHO, R. (Org.), Desenvolvimento capitalista no Brasil: ensaios sobre a crise. São Paulo: Brasiliense, vol. 1.

SINGER, Paul. (1975a), A Crise do "Milagre": interpretação crítica da economia brasileira. Rio de Janeiro: Paz e Terra.

SINGER, Paul. (1975b), "Desenvolvimento e repartição da renda no Brasil”. In: TOLIPAN, Ricardo e TINELLI, Arthur Carlos. (Orgs.). A Controvérsia sobre Distribuição de Renda e Desenvolvimento. Rio de Janeiro: Zahar Editores.

SOUZA, Celina. (2016a), "Políticas de desenvolvimento e expansão da capacidade do Estado no Brasil” In DINIZ, Eli e GAITÁN, Flavio. (Orgs.). Repensando o Desenvolvimentismo: Estado, Instituições e a construção de uma nova agenda de desenvolvimento para o século XXI. São Paulo-Rio de Janeiro: Hucitec Editora-INCT/PPED.

SOUZA, Celina. (2016b), “Capacidade burocrática no Brasil e na Argentina: Quando a política faz a diferença”. In Alexandre de Ávila Gomide e Renato Raul Boschi (Orgs.), Capacidades Estatais em Países Emergentes - o Brasil em perspectiva comparada. Brasília: IPEA. Retrieved November 11, 2018, from: http://www.ipea.gov.br/portal/images/stories/PDFs/livros/livro_capacidades.pdf

TAVARES, Maria da Conceição. (1973), Da Substituição de Importações ao Capitalismo Financeiro. Rio de Janeiro: Zahar.

TAVARES, Maria da Conceição. (1975), “Distribuição de renda, acumulação e padrões de industrialização: um ensaio preliminar”. In: TOLIPAN, Ricardo e TINELLI, Arthur Carlos. (Orgs.). A Controvérsia sobre Distribuição de Renda e Desenvolvimento. Rio de Janeiro: Zahar Editores. 
TAVARES, Maria da Conceição. (1983), “O Sistema Financeiro Brasileiro e o Ciclo de Expansão Recente” In BELLUZZO, Luiz Gonzaga M. e COUTINHO, Renata (Orgs.), Desenvolvimento Capitalista no Brasil: Ensaios sobre a Crise. São Paulo: Brasiliense, vol.2.

TAVARES, Maria da Conceição e ASSIS, João Carlos de. (1985), O Grande Salto para o Caos: a economia política e a política econômica do regime autoritário. Rio de Janeiro: Jorge Zahar Ed.

TAVARES, Maria da C. e BELLUZZO, Luiz G. de M. (1982), "Notas Sobre o Processo de Industrialização Recente no Brasil” In: BELLUZZO, Luiz Gonzaga M. e COUTINHO, Renata (Orgs.), Desenvolvimento Capitalista no Brasil: Ensaios sobre a Crise. Brasiliense: São Paulo, vol.1.

SINGER, Paul. (1975a), A Crise do "Milagre": interpretação crítica da economia brasileira. Rio de Janeiro: Paz e Terra.

SINGER, Paul. (1975b), “Desenvolvimento e repartição da renda no Brasil”. In: TOLIPAN, Ricardo e TINELLI, Arthur Carlos. (Orgs.). A Controvérsia sobre Distribuição de Renda e Desenvolvimento. Rio de Janeiro: Zahar Editores.

SOUZA, Paulo Renato. (1983), “Os Impasses Atuais das Políticas de Emprego e de Salário” In BELLUZZO, Luiz Gonzaga M. e COUTINHO, Renata (Orgs.), Desenvolvimento Capitalista no Brasil: Ensaios sobre a Crise. São Paulo: Brasiliense, vol.2.

VIANNA, Maria Lucia. T. W (1987). A Administração do Milagre: O Conselho Monetário Nacional 1964-1974. Rio de Janeiro: Vozes.

WERNECK, Rogério L. F. (1983), "Estrangulamento Externo e Investimento Público". In: ARIDA, Pérsio (Org.), Divida Externa, Recessão e Ajuste Estrutural: o Brasil diante da crise. Rio de Janeiro: Paz e Terra. 